\title{
A Critical Review on Air Quality Studies in Different Regions of India
}

\author{
${ }^{1}$ Raja, ${ }^{2}$ Rahul Silori, ${ }^{3}$ Anubhav Kumar, ${ }^{4}$ Sonal Behera, ${ }^{5}$ Abhishek Ranjan \\ ${ }^{1,2,3,4}$ HSE and Civil Engineering Department, ${ }^{5}$ Mechanical Engineering Department \\ University of Petroleum and Energy Studies, Dehradun \\ ${ }^{1}$ rajayad1632@gmail.com \\ rrsilori@ddn.upes.ac.in
}

\begin{abstract}
Air quality in India is a field of bother. There has been a constant degradation in the quality of air from the past few years. According to the reports of WHO/UNEP (1992), some of the metropolitan cities in India are in the list of most polluted cities in the world. The poor air quality directly affects the ecosystem and has a major impact on the human health. The contamination of pollutants mainly $\mathrm{SO}_{2}, \mathrm{NO}_{2}, \mathrm{RSPM}$, and $\mathrm{PM}_{10}$ are responsible for poor air quality. Statistics show that 4-5 million people die each year around the globe due to poor air quality. The highest death recorded was 7 million in the year 2012. Poor air quality leads to breathing problems and directly affects the internal respiratory organs of the body. The ambient air standard is analyzed with the help of air quality index (AQI) which gives a relative measure for ambient air concentration. This review paper gives an idea about the air quality in some of the expeditious flourishing regions of India. The study also enlightens the effect of parameters such as $\mathrm{SO}_{2}, \mathrm{NO}_{2}$, RSPM, and $\mathrm{PM}_{10}$ on to air pollution and the need for the measures against the poor air quality.
\end{abstract}

Keywords: Air quality, Air quality index (AQI), Respirable suspended particulate matter (RSPM), Ecosystem.

\section{INTRODUCTION}

India is a vast country with variety of people having different culture. Statistics shows that, population of India in year 2018 was around 1,358,137,719. India is one of the developing nations; therefore there is need for the perfection in field such as education, agriculture, proper sanitation, curability of diseases, traffic control and safety, maintenance of good air quality, etc. The perfection in these fields cannot be achieved easily due to its vast population but it will be a major threat to the human population, if the problem such as poor air quality is left masked!

There are varieties of environmental problems that are present in India. Among all problems, degradation in quality of air is one of the important problems that have drawn the attention. The quality of air is much paramount coz... air is used for inhalation and exhalation process by almost every living organism on earth. On the authority of the data obtained, it is seen that the level is pollution is crossing its permissible standard value in around 23 cities possessing the population over 1 million (Gupta et al., 2002). The degradation in the quality of air occurs due to different factors such as vehicular pollution, industrialization, burning of fossil fuels, etc. Amid the factors, contribution of vehicular pollution is high for degrading the quality of air. Among the total pollution caused in cities like Delhi, Mumbai and Kolkata, 70\% of pollution in Delhi, $52 \%$ of pollution in Mumbai and $30 \%$ of pollution in Kolkata is caused due to vehicular pollution (C.P.C.B., 2003). The pollutants that cause the air quality degradation are majorly $\mathrm{SO}_{2}, \mathrm{NO}_{2}, \mathrm{RSPM}$, and $\mathrm{PM}_{10}$.

The rise of the needs of the people has led to the industrialization in different parts of the country. The approximation done by United Nations read that in the total of 8.1 billion residents, 4.9 billion of resident would be residing in the cities by the year 2030 (UNSCD, 2001). The rate of the industrialization is high, which has led to the rapid increase in number of vehicles and these factors have disturbed the natural balance (Chauhan, 2008) directly affecting the air quality.

The quality of air directly affects the human health causing respiratory problems and different types of diseases that may lead an individual to death. The burning of fossil fuels and automobile emissions are major source for quality degradation of air quality, which is a genesis for disease and problems related to 
health (AlliraniThiyagarajan, 2003). Among the pollutants discussed, the effect of suspended particulate matter (SPM) on to the health is supplemental. The size of the SPM plays a crucial role in harming the respiratory systems that is size of diameter less than $10 \mu \mathrm{m}$ gets into the lungs easily causing breathing problems (Healy et al., 2007). As these are harmful to health hence, there is a need for effective steps against air quality.

This paper presents the previous studies conducted by assorted researchers to enhance the knowledge about the ambient air quality of the expeditious flourishing regions of India such as Maharashtra, Chennai, Delhi and Uttarakhand. This paper also reviews the effect of poor air quality on health, the extent in which it affects the people and at last gives some optimistic remedial solutions for improvement in air quality.

\section{AMBIENT AIR QUALITY IN}

MAHARASHTRA (Lomate Varsha U, 2015)

The study was conducted in the state of Maharashtra on the identified districts. The objective of this study was to analyze the growth levels of air pollutants, mainly $\mathrm{SO}_{2}, \mathrm{NO}_{2}, \mathrm{RSPM}$ (Respirable suspended particulate matter). Six districts of Maharashtra were selected and the data of ambient air quality from the year 2013-14 were obtained viz... Maharashtra pollution control board (MPCB). The data obtained from the MPCB were analyzed and the levels of the three pollutants $\left(\mathrm{SO}_{2}, \mathrm{NO}_{2}\right.$, and RSPM) were checked. The obtained concentrations were compared from the max allowed concentrations of the three respective pollutants. The analysis of results showed that RSPM played a major role as a contributor towards contamination of air. Comparison of the min, max and average concentration of the three pollutants are shown in the table below.

Table 1: Variations of the min, max, and average concentrations of $\mathrm{SO}_{2}, \mathrm{NO}_{2}$, and $\mathrm{RSPM}$ in year 2013 (microgram per cubic meter) (Lomate Varsha U, 2015)

\begin{tabular}{|c|c|c|c|c|c|c|c|c|c|}
\hline & $\mathrm{SO}_{2}$ & $\mathrm{SO}_{2}$ & $\mathrm{SO}_{2}$ & $\mathrm{NO}_{2}$ & $\mathrm{NO}_{2}$ & $\mathrm{NO}_{2}$ & RSPM & RSPM & RSPM \\
\hline Limits & 80 & 80 & 80 & 80 & 80 & 80 & 100 & 100 & 100 \\
\hline Mumbai (Sion) & 2 & 81 & 09 & 24 & 268 & 117 & 20 & 428 & 138 \\
\hline $\begin{array}{c}\text { Pune (Swargate) } \\
\text { max }\end{array}$ & 10 & 45 & 19 & 14 & 114 & 44 & 13 & 188 & 71 \\
\hline $\begin{array}{c}\text { Nashik (NMC } \\
\text { building) }\end{array}$ & 21 & 43 & 28 & 22 & 44 & 29 & 35 & 182 & 86 \\
\hline $\begin{array}{c}\text { Aurangabad } \\
\text { (CADA office) }\end{array}$ & 7 & 16 & 10 & 28 & 51 & 37 & 23 & 129 & 70 \\
\hline $\begin{array}{c}\text { Amravati (govt } \\
\text { college of engg) }\end{array}$ & 5 & 15 & 11 & 06 & 16 & 12 & 35 & 110 & 82 \\
\hline $\begin{array}{c}\text { Nagpur (Regional } \\
\text { office of MPCB) }\end{array}$ & 5 & 21 & 09 & 12 & 69 & 25 & 15 & 216 & 59 \\
\hline
\end{tabular}


It was seen that the concentration of $\mathrm{SO}_{2}, \mathrm{NO}_{2}$, and RSPM reached above its allowable limited value in Mumbai district. The concentration of $\mathrm{NO}_{2}$, RSPM was also seen higher than its limited value in Pune. In the rest of the four districts, the concentration of $\mathrm{SO}_{2}$, $\mathrm{NO}_{2}$ was found to be less than the limited value except RSPM concentration.

Table 2: Variations of the min, max and average concentrations of $\mathrm{SO}_{2}, \mathrm{NO}_{2}$, and RSPM in year 2014 (microgram per cubic meter) (Lomate Varsha U, 2015)

\begin{tabular}{|c|c|c|c|c|c|c|c|c|c|}
\hline & \multicolumn{3}{|c|}{$\mathrm{SO}_{2}$} & \multicolumn{3}{|c|}{$\mathrm{NO}_{2}$} & \multicolumn{3}{|c|}{ RSPM } \\
\hline Limit & \multicolumn{3}{|c|}{80} & \multicolumn{3}{|c|}{80} & \multicolumn{3}{|c|}{80} \\
\hline & MIN & MAX & AVE & MIN & MAX & AVE & MIN & MAX & AVE \\
\hline MUMBAI (SION) & 2 & 86 & 10 & 5 & 208 & 93 & 36 & 390 & 129 \\
\hline PUNE SWARGATE & 12 & 51 & 23 & 16 & 105 & 45 & 8 & 268 & 79 \\
\hline NASHIK_NMC building & 5 & 34 & 25 & 16 & 46 & 27 & 34 & 138 & 73 \\
\hline $\begin{array}{l}\text { AURANGABAD(CADA } \\
\text { Office) }\end{array}$ & 7 & 37 & 12 & 26 & 77 & 39 & 15 & 153 & 77 \\
\hline $\begin{array}{l}\text { AMRAVATI (GOVT } \\
\text { College of Engg.) }\end{array}$ & 5 & 14 & 11 & 6 & 16 & 12 & 42 & 108 & 77 \\
\hline $\begin{array}{l}\text { NAGPUR (REG Office OF } \\
\text { MPCB) }\end{array}$ & 7 & 14 & 19 & 16 & 45 & 26 & 27 & 117 & 64 \\
\hline
\end{tabular}

The pictorial representation of average concentration of the three pollutants obtained in the year 2013-14 was shown in bar chart. From the bar chart shown below it can be concluded that RSPM concentration was higher than its limited value in each of the six selected districts. From the bar charts it was also seen that the other pollutants concentration was also higher than permissible value. 
International Journal of Research in Advent Technology, Vol.7, No.2, February 2019 E-ISSN: 2321-9637

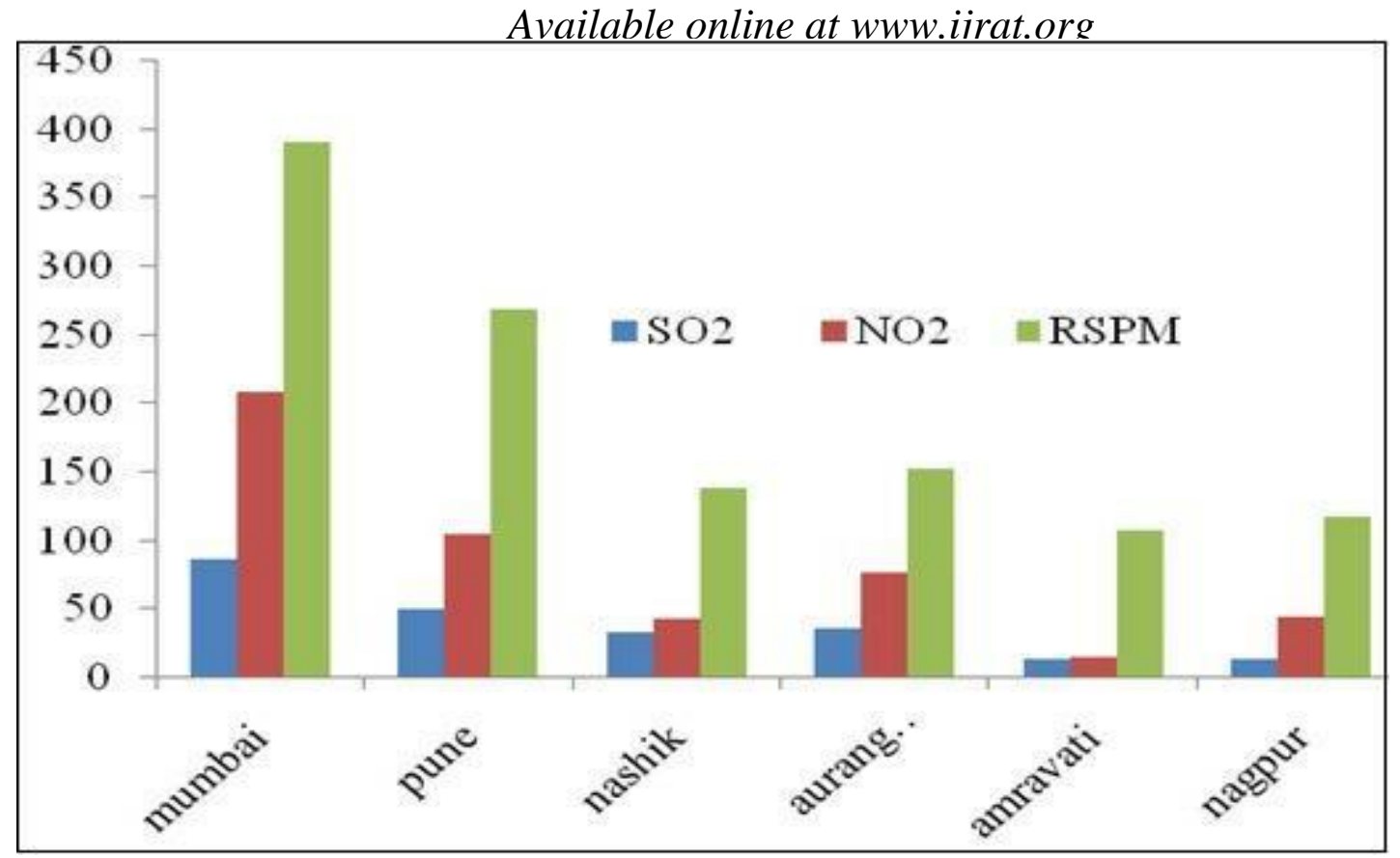

Figure 1: Average concentration of $\mathrm{SO}_{2}, \mathrm{NO}_{2}$ and RSPM for all the six selected districts in the year 2014(Lomate Varsha U, 2015)

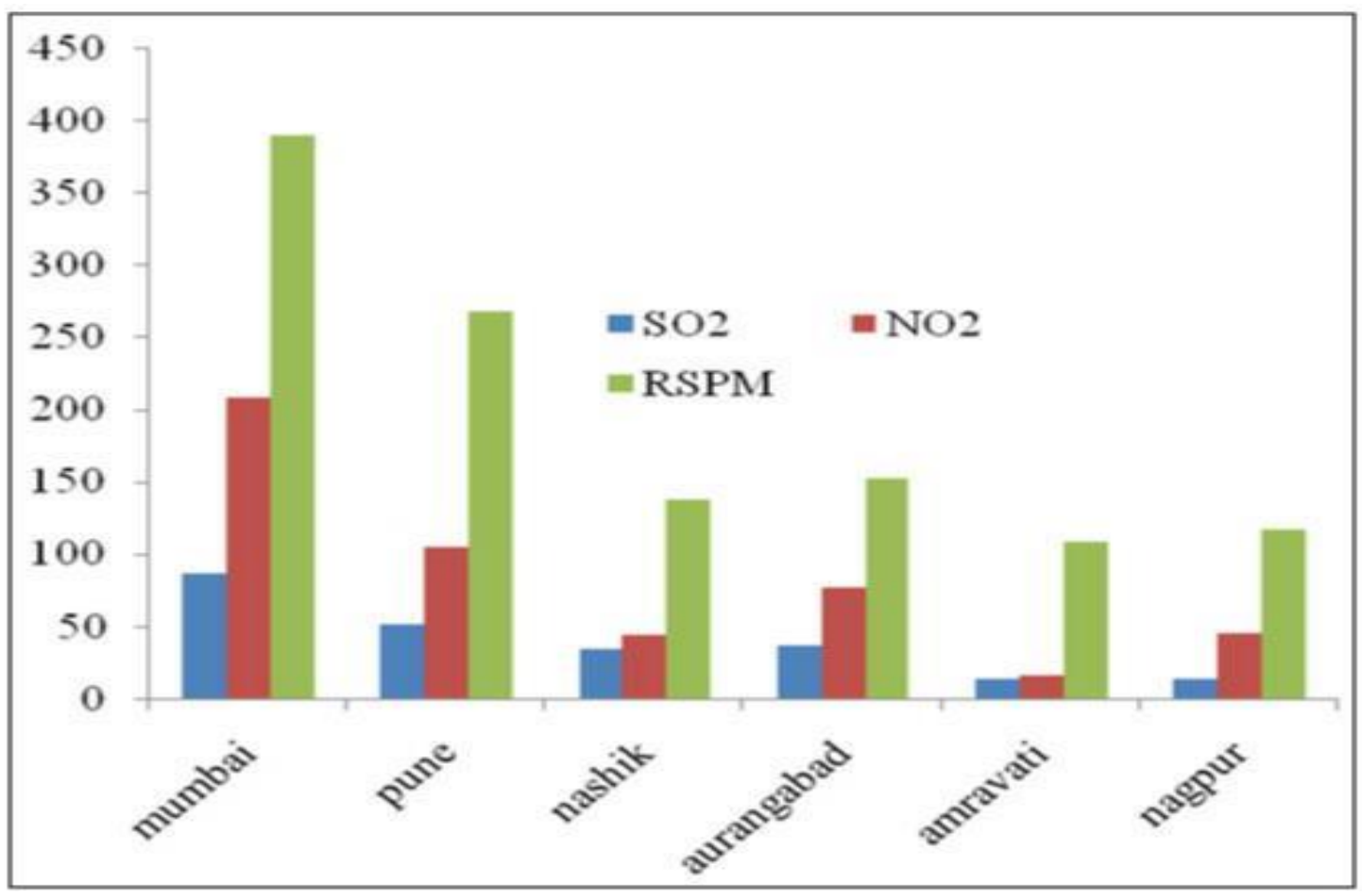

Figure 2: Average concentration of $\mathrm{SO}_{2}, \mathrm{NO}_{2}$ and RSPM for all the six selected districts in the year 2013 (Lomate Varsha U, 2015) 
From the figure it can be analyzed that the concentration of RSPM is slightly decreased in the year 2014 when compared to the year 2013.

\section{AMBIENT AIR QUALITY IN CHENNAI (Thilagaraj et.al, 2014)}

The study was conducted in the Chennai city. The main objective of this study was to analyze the air quality of the Chennai. Five random places were selected namely Anna Nagar, Adyar, Kilpauk, T. Nagar, V. Nagar.
The data of ambient air quality from the year 2007 to 2012 was collected from Tamil Nadu Pollution Control Board (TNPCB). The data obtained for ambient air quality was used for the calculation of monthly wise air quality index (AQI) from year 2007-2014.

The obtained AQI after the calculation was then compared from the standard AQI that is proposed for India. The quality of air was decided based on the index value obtained. Below table shows the standard value of AQI proposed for India:

Table 1: Permissible/standard value of AQI for India (Thilagaraj et.al (2014), Sharma et al., 2003)

\begin{tabular}{|c|c|c|c|c|c|c|}
\hline S.No & Index & Category & $\begin{array}{c}\mathrm{SO}_{2}(24 \mathrm{hr} \\
\text { avg }) \\
(\mu \mathrm{g} / \mathrm{m} 3)\end{array}$ & $\begin{array}{c}\mathrm{NO}_{2}(1 \mathrm{hr} \\
\text { avg }) \\
(\mu \mathrm{g} / \mathrm{m3})\end{array}$ & $\begin{array}{c}\text { SPM(24hr } \\
\text { avg) } \\
(\mu \mathrm{g} / \mathrm{m} 3)\end{array}$ & $\begin{array}{c}\mathrm{PM}_{10}(24 \mathrm{hr} \\
\text { avg }) \\
(\mu \mathrm{g} / \mathrm{m3})\end{array}$ \\
\hline 1 & $0-100$ & Good & $0-80$ & $0-80$ & $0-200$ & $0-100$ \\
\hline 2 & $101-200$ & Moderate & $81-367$ & 81-180 & $201-260$ & $101-150$ \\
\hline 3 & $201-300$ & Poor & $368-786$ & $181-564$ & $261-400$ & $151-350$ \\
\hline 4 & $301-400$ & $\begin{array}{l}\text { Very } \\
\text { poor }\end{array}$ & 787-1572 & $565-1272$ & $401-800$ & $351-420$ \\
\hline 5 & $401-500$ & Severe & $>1572$ & $>1272$ & $>800$ & $>420$ \\
\hline
\end{tabular}

The monthly wise obtained AQI for each selected region from the year 2007-2012 was represented in tabular format as shown below for easy analyzing.

Table 2: Calculated AQI for the region of T.Nagar (Thilagaraj et.al, 2014)

\begin{tabular}{|l|c|c|c|c|c|c|}
\hline & 2007 & 2008 & 2009 & 2010 & 2011 & 2012 \\
\hline JANUARY & 94 & 105 & 105 & 154 & 154 & 123 \\
\hline
\end{tabular}


International Journal of Research in Advent Technology, Vol.7, No.2, February 2019

E-ISSN: 2321-9637

Available online at www.ijrat.org

\begin{tabular}{|l|c|c|c|c|c|c|}
\hline FEBRUARY & 119 & 129 & 207 & 109 & 119 & 125 \\
\hline MARCH & 101 & 141 & 132 & 170 & 103 & 164 \\
\hline APRIL & 100 & 98 & 98 & 125 & 137 & 111 \\
\hline MAY & 91 & 124 & 194 & 154 & 210 & 246 \\
\hline JUNE & 57 & 149 & 111 & 178 & 113 & 190 \\
\hline JULY & 91 & 182 & 170 & 133 & 92 & 92 \\
\hline AUGUST & 88 & 96 & 160 & 160 & 182 & 96 \\
\hline SEPTEMBR & 90 & 113 & 182 & 167 & 287 & 176 \\
\hline OCTOBER & 97 & 121 & 160 & 177 & 279 & 176 \\
\hline NOVEMBER & 135 & 144 & 164 & 83 & 255 & 271 \\
\hline DECEMBER & 143 & 162 & 204 & 129 & 253 & 107 \\
\hline
\end{tabular}

Table 3: Calculated AQI for the region of Kilpauk (Thilagaraj et.al, 2014)

\begin{tabular}{|c|c|c|c|c|c|c|}
\hline & 2007 & 2008 & 2009 & 2010 & 2011 & 2012 \\
\hline JANUARY & 94 & 156 & 156 & 95 & 44 & 92 \\
\hline FEBRUARY & 99 & 139 & 121 & 94 & 115 & 271 \\
\hline MARCH & 117 & 149 & 113 & 130 & 135 & 541 \\
\hline APRIL & 100 & 95 & 95 & 98 & 162 & 301 \\
\hline MAY & 91 & 123 & 143 & 76 & 113 & 301 \\
\hline JUNE & 81 & 103 & 86 & 99 & 81 & 212 \\
\hline JULY & 129 & 79 & 119 & 78 & 127 & 162 \\
\hline AUGUST & 52 & 87 & 94 & 87 & 176 & 170 \\
\hline SEPTEMBER & 147 & 200 & 119 & 97 & 137 & 168 \\
\hline OCTOBER & 154 & 135 & 99 & 93 & 125 & 160 \\
\hline NOVEMBER & 200 & 165 & 149 & 63 & 86 & 170 \\
\hline DECEMBER & 182 & 128 & 119 & 79 & 170 & 115 \\
\hline
\end{tabular}

A total of 91 questionnaires were done in all the selected places and the statistics showed that about half of them were suffering from the disease. After obtaining the results for each region, Kilpauk was declared as the most polluted place in Chennai.

\section{AMBIENT AIR QUALITY IN DELHI (Paradkar et.al, 2016)}

The study was conducted in different parts of Delhi. The main objective of the study was to analyze 
different parameters and there concentration in the selected parts of the city.

The test was conducted on the parameters Ammonia, Benzene, Nitrogen dioxide, Sulphur dioxide and Particulate matter $\left(\mathrm{PM}_{10}\right)$ in the selected areas of Delhi (Civil lines, Punjabi Bagh, Anand Vihar).The data was viewed and analyzed by Ministry of Environment and Forest, India
From the study, it was observed that the major cause of air pollution was combustion. It was observed that other factors in fuel like Poor fuel to air ratio or too high or too low combustion temperature also causes the formation of side products which make the air polluted. Below table shows Ambient air quality checks are done in various parts of cities.

Table 1: Concentration variation of selected parameters in Civil Lines (Paradkar et.al, 2016)

\begin{tabular}{|l|c|c|}
\hline Parameters & Particulate matter PM10 & Prescribed standards \\
\hline Ammonia & $54.54 \mu \mathrm{g} / \mathrm{m} 3$ & $400 \mu \mathrm{g} / \mathrm{m} 3$ \\
\hline Benzene & $4.94 \mu \mathrm{g} / \mathrm{m} 3$ & $5 \mu \mathrm{g} / \mathrm{m} 3$ \\
\hline Nitrogen dioxide & $146.51 \mu \mathrm{g} / \mathrm{m} 3$ & $\mathbf{8 0} \mu \mathrm{g} / \mathrm{m} 3$ \\
\hline Sulphur dioxide & $14.29 \mu \mathrm{g} / \mathrm{m} 3$ & $\mathbf{8 0} \mu \mathrm{g} / \mathrm{m} 3$ \\
\hline Particulate matter PM10 & $284.61 \mu \mathrm{g} / \mathrm{m} 3$ & $\mathbf{1 0 0} \mu \mathrm{g} / \mathrm{m} 3$ \\
\hline
\end{tabular}

Table 2: Concentration variation of selected parameters in Punjabi Bagh (Paradkar et.al, 2016)

\begin{tabular}{|l|c|c|}
\hline \multicolumn{1}{|c|}{ Parameters } & Gas concentrations & Prescribed standards \\
\hline Ammonia & $21.4 \mu \mathrm{g} / \mathrm{m} 3$ & $400 \mu \mathrm{g} / \mathrm{m} 3$ \\
\hline Benzene & $\mathbf{0 . 5} \mu \mathrm{g} / \mathrm{m} 3$ & $5 \mu \mathrm{g} / \mathrm{m} 3$ \\
\hline Nitrogen dioxide & $107.5 \mu \mathrm{g} / \mathrm{m} 3$ & $80 \mu \mathrm{g} / \mathrm{m} 3$ \\
\hline Sulphur dioxide & $20.7 \mu \mathrm{g} / \mathrm{m} 3$ & $80 \mu \mathrm{g} / \mathrm{m} 3$ \\
\hline Particulate matter PM10 & $165 \mu \mathrm{g} / \mathrm{m} 3$ & $100 \mu \mathrm{g} / \mathrm{m} 3$ \\
\hline Particulate matter PM2.5 & $35 \mu \mathrm{g} / \mathrm{m} 3$ & $60 \mu \mathrm{g} / \mathrm{m} 3$ \\
\hline
\end{tabular}

Table 3: Concentration variation of selected parameters in Anand Vihar (Paradkar et.al, 2016)

\begin{tabular}{|c|c|c|}
\hline Parameters & Gas concentrations & Prescribed standards \\
\hline Ammonia & $56.8 \mu \mathrm{g} / \mathrm{m} 3$ & $400 \mu \mathrm{g} / \mathrm{m} 3$ \\
\hline Benzene & $15.1 \mu \mathrm{g} / \mathrm{m} 3$ & $5 \mu \mathrm{g} / \mathrm{m} 3$ \\
\hline Nitrogen dioxide & $96.6 \mu \mathrm{g} / \mathrm{m} 3$ & $80 \mu \mathrm{g} / \mathrm{m} 3$ \\
\hline Sulphur dioxide & $28.7 \mu \mathrm{g} / \mathrm{m} 3$ & $80 \mu \mathrm{m} / \mathrm{m} 3$ \\
\hline Particulate matter PM10 & $230 \mu \mathrm{g} / \mathrm{m} 3$ & $100 \mu \mathrm{g} / \mathrm{m} 3$ \\
\hline Particulate matter PM2.5 & $77 \mu \mathrm{g} / \mathrm{m} 3$ & $60 \mu \mathrm{g} / \mathrm{m} 3$ \\
\hline
\end{tabular}

The above table shows different gas concentration and the prescribed standard of the parameters it was observed that Particulate matter $\mathrm{PM}_{10}$ is very much higher than the prescribed standard in all the three parts of the city. It was also seen that even Nitrogen dioxide was crossing the limits.

\section{AMBIENT AIR QUALITY IN UTTARAKHAND (Chauhan et.al, 2014)}

The status was studied in different seasons at four sites of Uttarakhand which are Shivalik Nagar Haridwar, SIDCUL Haridwar, Clock tower Dehradun and The Agricultural areas of the Uttarakhand. The 
International Journal of Research in Advent Technology, Vol.7, No.2, February 2019

E-ISSN: 2321-9637

Available online at www.ijrat.org

major pollutant which was checked in those areas was PM $_{10}$ (RSPM), SPM (Suspended Particulate

Matter), $\mathrm{SO}_{2}$ (Sulphur Dioxide) and $\mathrm{NO}_{\mathrm{x}}$ (Oxides of Nitrogen).

Table 1: Concentration variation of different pollutant at the selected area's (Chauhan et.al, 2014)

\begin{tabular}{|c|c|c|c|c|c|}
\hline \multirow{2}{*}{$\begin{array}{l}\text { S. } \\
\text { No }\end{array}$} & \multirow[t]{2}{*}{ Pollutant } & \multirow{2}{*}{$\begin{array}{l}\text { Time- } \\
\text { weighted } \\
\text { average }\end{array}$} & \multicolumn{3}{|c|}{ Concentration in ambient air } \\
\hline & & & $\begin{array}{c}\text { Industrial } \\
\text { Areas, } \\
\text { Residential, } \\
\text { Rural AREA }\end{array}$ & $\begin{array}{l}\text { Ecological } \\
\text { Sensitive Area }\end{array}$ & Methods of Measurement \\
\hline \multirow[t]{2}{*}{1.} & \multirow[t]{2}{*}{$\begin{array}{l}\text { Sulphur } \\
\text { Dioxide } \\
\left(\mathrm{SO}_{2}\right)\end{array}$} & $\begin{array}{l}\text { Annual } \\
\text { Average }\end{array}$ & $50 \mu \mathrm{g} / \mathrm{m}^{\jmath}$ & $20 \mu \mathrm{g} / \mathrm{m}^{\nu}$ & \multirow[t]{2}{*}{$\begin{array}{l}\text {-Improved West and Greek } \\
\text { method } \\
\text {-Ultraviolet Flurorescence }\end{array}$} \\
\hline & & 24 hours & $80 \mu \mathrm{g} / \mathrm{m}^{3}$ & $80 \mu \mathrm{g} / \mathrm{m}^{3}$ & \\
\hline \multirow[t]{2}{*}{2.} & \multirow{2}{*}{$\begin{array}{l}\text { Oxides of } \\
\text { Nitrogen } \\
\text { as } \\
\left(\mathrm{NO}_{2}\right)\end{array}$} & $\begin{array}{l}\text { Annual } \\
\text { Average }\end{array}$ & $40 \mu \mathrm{g} / \mathrm{m}^{\nu}$ & $30 \mu \mathrm{g} / \mathrm{m}^{\nu}$ & \multirow[t]{2}{*}{$\begin{array}{l}\text {-Modified Jacob and } \\
\text { Hochheiser } \\
\text {-Chemiluminescence }\end{array}$} \\
\hline & & 24 hours & $80 \mu \mathrm{g} / \mathrm{m}^{3}$ & $80 \mu \mathrm{g} / \mathrm{m}^{3}$ & \\
\hline \multirow[t]{2}{*}{3.} & \multirow[t]{2}{*}{$\begin{array}{l}\text { Suspended } \\
\text { Particulate } \\
\text { Matter }\end{array}$} & $\begin{array}{l}\text { Annual } \\
\text { Average }\end{array}$ & $60 \mu \mathrm{g} / \mathrm{m}^{\jmath}$ & $60 \mu \mathrm{g} / \mathrm{m}^{\nu}$ & \multirow[t]{2}{*}{$\begin{array}{l}\text {-Gravimetric } \\
\text {-TOEM } \\
\text {-Beta attenuation }\end{array}$} \\
\hline & & 24 hours & $100 \mu \mathrm{g} / \mathrm{m}^{3}$ & $100 \mu \mathrm{g} / \mathrm{m}^{3}$ & \\
\hline \multirow[t]{2}{*}{4.} & \multirow[t]{2}{*}{$\begin{array}{l}\text { Respirable } \\
\text { Suspended } \\
\text { Particulate } \\
\text { Matter }\end{array}$} & $\begin{array}{l}\text { Annual } \\
\text { Average }\end{array}$ & $40 \mu \mathrm{g} / \mathrm{m}^{\jmath}$ & $40 \mu \mathrm{g} / \mathrm{m}^{\nu}$ & \multirow[t]{2}{*}{$\begin{array}{l}\text {-Gravimetric } \\
\text {-TOEM } \\
\text {-Beta attenuation }\end{array}$} \\
\hline & & 24 hours & $60 \mu \mathrm{g} / \mathrm{m}^{\nu}$ & $60 \mu \mathrm{g} / \mathrm{m}^{\nu}$ & \\
\hline
\end{tabular}

The above table shows pollutant time and the concentration of pollutant in the air from the table it was observed that the level of Sulphur dioxide and oxides of nitrogen was observed higher in the ecological sensitive areas. 

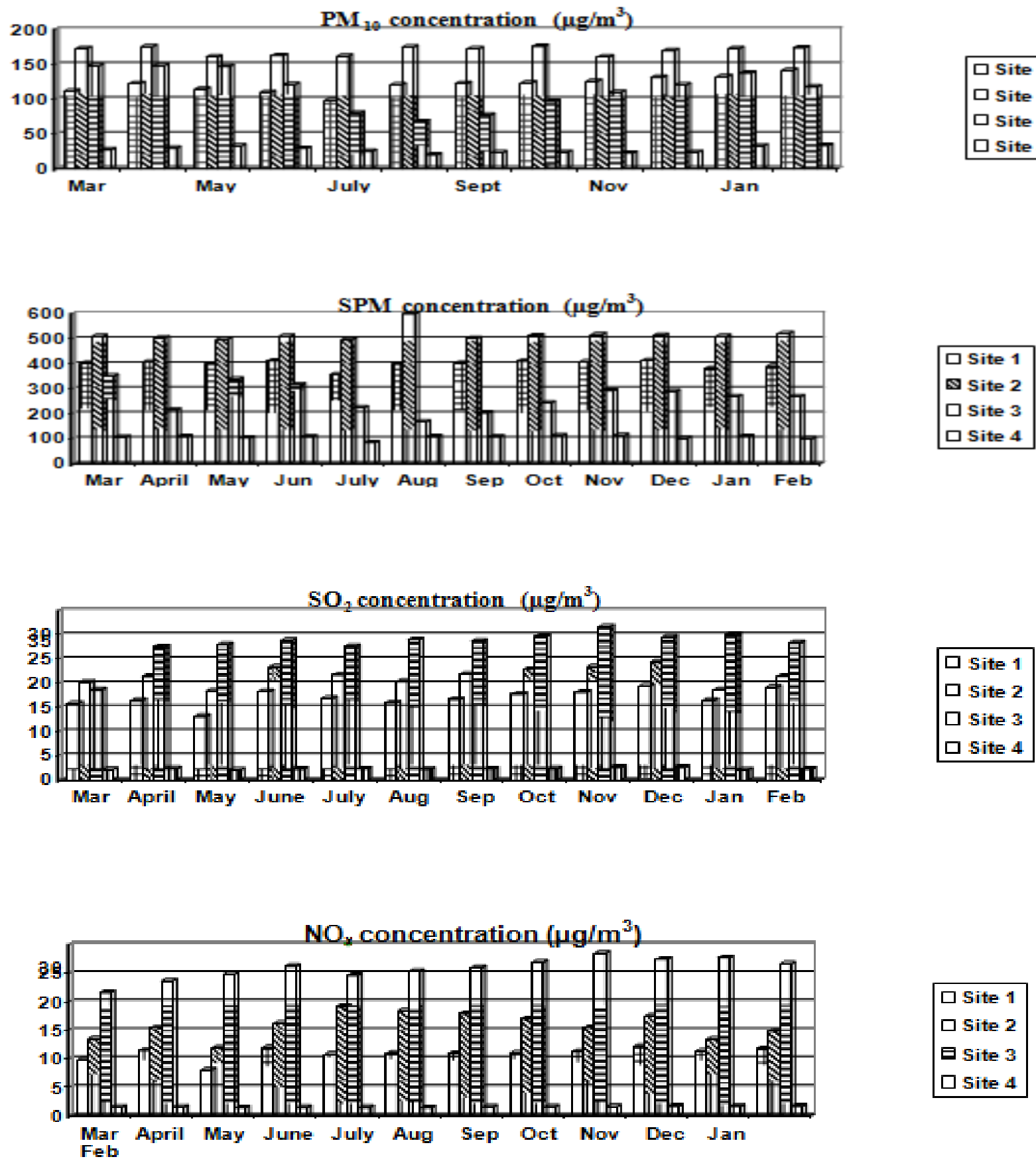

Figure 1: Shows the concentrations of the pollutants in different months at selected sites. (Chauhan et.al, 2014)

It is seen from the figure that concentration of $\mathrm{PM}_{10}$ and SPM was much higher than $\mathrm{SO}_{2}$ and $\mathrm{NO}_{\mathrm{x}}$. Hence, $\mathrm{PM}_{10}$ and SPM are causing major threat as the concentrations of these are higher enough than the others.

\section{CONCLUSION}

Technological development in future for improving the quality of air needs a background of previous research studies. This review paper gives idea about the levels of pollutant in different cities. It has been 


\section{International Journal of Research in Advent Technology, Vol.7, No.2, February 2019 E-ISSN: 2321-9637 \\ Available online at www.ijrat.org}

observed that in metro cities the level of pollutant is increasing drastically. Numerous growth of industries, increase in daily traffic are some of the major causes of degradation of air quality. The poor air quality causes breathing problems and different types of disease such as asthma, etc, resulting in large amount of death.

This review finds that the level of $\mathrm{SO}_{2}, \mathrm{NO}_{2}$, and RSPM reached above the allowable limited value in Mumbai district which reflects that rate of pollution in this city is high. This could be due to vehicular pollution as this city is much crowded than the normal cities. The level of pollution was also high in the Chennai city and from the statistics it was found that around $50 \%$ of them were suffering from disease which in terms shows that the rate of degradation of air quality in this is high.

Hence the quality of air should be improved to avoid disease and deaths. Following methods and techniques can be adopted for refinement of air quality:

1) Car pool reduces the use of old vehicles, reducing the pollution as the old vehicles liberate large amount of toxic gases into the atmosphere.

2) Height of the chimneys provided should be high enough so that the resident's don't get affected.

3) Introducing more amounts of CNG vehicles for public would have a greater impact, as most of the air quality is degraded by vehicular pollution.

4) Gas connection provision to public would reduce the burning of fossil fuel for house hold purpose. Hence, reducing the pollution

This review paper shows that in most of the selected expeditious flourishing regions of India, the contamination of air is high! Hence, this paper plays a major role in warning about the problems that could arise in the future due to poor air quality.

\section{ACKNOWLEDGEMENT:}

The authors would like to express their sincere gratitude to all the referred research papers and a special thanks to faculty Mr. Rahul Silori for providing guidance to carry out the review.

\section{REFERENCES:}

[1] Thilagaraj, P., Ravinder, R., \&Kesavan, R. (2014). A study on air pollution and its impact on human health in Chennai city. IOSR Journal of Mechanical and Civil Engineering, 4, 1-5.
[2] Lomate Varsha U (2015). Studies on Air quality of Maharashtra, India.

a. http://www.isca.in/IJENS/Archive/v4/i10/5.ISC A-IRJEVS-2015-170.pdf

[3] Chauhan, A., Pawar, M., Kumar, R., \& Joshi, P. C. (2010). Ambient air quality status in Uttarakhand (India): a case study of Haridwar and Dehradun using air quality index. Journal of American Science, 6(9), 565-574.

[4] http://www.ijstm.com/images/short_pdf/1459435 749 1200B.pdf

[5] CPCB 2003. Parivesh: Polycyclic Aromatic Hydrocarbons (PAHs) in air and their effects of human health, November 2003, Central Pollution Control Board, Ministry of Environment and Forest, Delhi-32,

[6] CPCB (2001). National ambient air quality statistics of India. Central Pollution Control Board, Parivesh Bhavan, Delhi, India

[7] Chauhan, A. and Joshi, P.C. 2008. Air quality index and its variations in Haridwar. Journal of Environment and Biosciences, 22 (2), 171-176.

[8] Healy, D., Silvari, V., Whitaker, A., Lopez, J., PereTrepat, E., Heffron, E., (2007). Linking urban field measurements of ambient air particulate matter to their chemical analysis and effects on health. In Proceedings of the 6th International Conference on Urban Air Quality, Limassol, Cyprus.

[9] UNCSD 2001. Protection of the AtmosphereReport to the Secretary General. E/CN.17/2001/2, Commission for Sustainable Development, New York, USA.

[10] Gupta, H.K., Gupta, V.B., Rao, C.V.C., Gajghate, D.G. and Hasan, M.Z. (2002). Urban air quality and its management strategy for am metropolitan city of India. Bull. Environ. Contam. Toxicol. 68, 347-354.

[11] WHO/UNEP Report. 1992. Urban air pollution in mega-cities of the world. World Health Organization and United Nations Environment Programme. Blackwell Publishers, 108 Cowley Road, Oxford OX4 IJF Cambridge, UK.

[12] AlliraniThiyagarajan (2003) Air Pollution and Respiratory Illness. Proceedings of the Third International Conference on Environment and Health, Chennai, India, 15-17 December 2003, pp 588- 596 